\title{
Managing Information Quality in B2C Companies: An Empirical Investigation on Halal e-Commerce Websites
}

\author{
https://doi.org/10.3991/ijim.v14i17.16651 \\ Mariana Jusop ${ }^{(凶)}$ \\ Universiti Sultan Zainal Abidin, Kuala Terengganu, Malaysia \\ mariana.jusop1982@gmail.com \\ Risyawati Mohamed Ismail \\ Universiti Utara Malaysia, Sintok, Malaysia \\ Noor Azizi Ismail \\ Universiti Malaysia Kelantan, Kota Bharu, Malaysia
}

\begin{abstract}
Ambiguous information, incomplete explanation and unclear description of products portrayed in a website normally caused carts abandonment. As evidenced in many prior studies, consumers' purchase intentions were highly influenced by their confidence in the information provided by the website. This study identifies criteria of qualified information and describes how it was managed by halal e-commerce businesses. Qualitative data were collected through in-depth interview with key information custodians from four e-commerce platforms. The study found good understanding and efficient management of information quality criteria could help halal ecommerce businesses to progress one-step ahead of their competitors.
\end{abstract}

Keywords-Websites-Commerce platform, information quality, Interview, halal, e-commerce.

\section{Introduction}

As the Internet evolved and matured, many businesses have taken advantage to incorporate it into their business models and use it to conduct most of their business activities. The technology has paved the way for businesses to make use of ecommerce websites as alternative sales channels due to increasing trends of online shopping. Trading over the Internet is usually referred to as Electronic Commerce (ecommerce). It involves the use of the Internet for buying and selling activities such as advertising, negotiations, and contracts (Simpson and Docherty, 2004).

Apparently, more organizations are aware that venturing into $\mathrm{B} 2 \mathrm{C}$ e-commerce could benefit them to increase sales from their websites. However, since consumers in the digital age have become increasingly informed, there is a challenge for the business to provide a qualified information to fully embrace buyers' preferences and expectations while navigating the website. In online commerce, the physical 
interactions between the trading parties are very minimum, or nonexistence. Therefore, the information provided by each party must be in a good quality so that the objective of the transactions could be achieved.

With the emerging trends in e-commerce adoption and numerous fraud cases reported regarding online transactions, many researchers show their concerns by dedicating research efforts in that area. For examples, Zhang, Chen and Zuo (2017) identified several problems faced by the companies such as fake customer information, fictitious trade, incompatible product information, false business promotion, and bad after sale services. While, Zhou et.al. (2018) evidenced that the lack of information transparency is one of the factors that lead to consumers' final abandonment of online purchases. This is because consumers consider that the website does not provide sufficient, complete, and correct information for making a purchase decision, resulting in refusal to make a purchase.

Therefore, this study uses the well established DeLone and McLean Information Systems Success Model to identify the criteria of the quality of e-commerce's information and services provided to the customers. Even though researches on ecommerce have been widely explored, and various characteristics of qualified information have been proposed such as confidentiality, integrity, compliance, availability, effectiveness, reliability, and efficiency, but very limited investigation was done in the halal e-commerce environment. We also believe that the criteria of information quality are not fixed to these lists, but may depend on the research area and objectives. This is the aim to be achieved by this study, i.e. to identify other relevant criteria of information quality in halal e-commerce and how these ecommerce providers manage that information.

\section{Literature Review}

E-commerce is the online process of buying and selling of goods or services, supported by technology applications such as email, website, online banking, and payment gateway. Among the most explored e-commerce model is business-toconsumer (B2C) e-commerce, which involve the direct selling of a product, service, and information from a business to many potential consumers through the Internet (Turban et al., 2017, 2018, p.7). Since this research is specifically focused to ecommerce platforms in the context of halal industry that offer the trading of halal products and services, the term "halal e-commerce" used. Therefore, halal ecommerce in this study refers to the practice of performing critical business process such as the trading of goods, services and information through the Internet that better reflect the Islamic point of view (Muhammad, Muhammad, \& Khalil, 2013; Amboala, et al., 2015; Ribadu \& Wan Ab Rahman, 2016; 2017; Turban, 2018; Jusop, Ismail and Ismail, 2018). 


\subsection{E-Commerce in halal industry}

Halal is an area that many emerging e-commerce platforms are seeking to address. The value of halal products traded via e-commerce was USD123 billion in 2015 and is expected to reach over USD230 billion in 2020 (Daganghalal, 2016). While, The State of the Global Islamic Economy Report 2015/16 predicted e-commerce spending by Muslims around the world is expected to reach USD252 billion in 2020. This indicates that the opportunity is wide open for all halal businesses including those which are small in size to reach out globally.

Due to growing dynamism of globalization, companies in the halal industry need to adapt to the changing trends in trading process such as the use of e-commerce technology. The advent of Internet has transformed the way people conduct their trade. In B2C e-commerce, consumer's preference for the convenience of online shopping has made e-commerce among the fastest growing sectors of the economy. Furthermore, businesses' ability to adopt the technology are growing to the extent that very minimum physical contact and interaction involved between sellers and buyers. Online buyers never met the sellers and could not touch the product until it is delivered to them. Therefore, to make sure the success of the transactions, both parties must provide a fair and adequate information about the dealings. For instance, the sellers are responsible to disclose complete information about their products and customers are to give their personal details as required by the sellers. The customer service function is also crucial even after the order is fulfilled and delivered to customers. The common transaction processes or activities of a $\mathrm{B} 2 \mathrm{C}$ e-commerce are depicted in Figure 1.

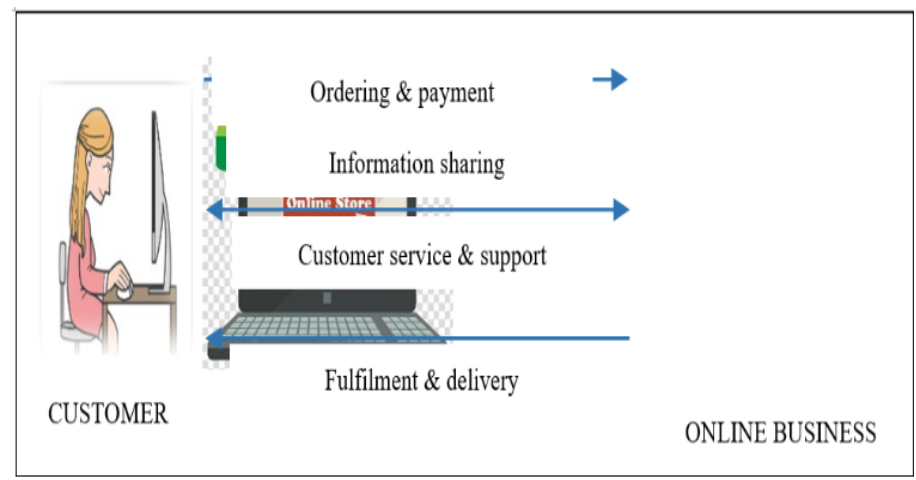

Fig.1. B2C e-commerce activities

Whether it is general e-commerce or halal e-commerce, these processes or activities are the same. However, when it comes to halal products and services offered through e-commerce, the emphasis on how each activity performed could be a different. Muslim consumers are concerned with the quality and wholesomeness of products they purchased (Majid, Abidin, Majid, \& Chik, 2015; Talib, Ali, \& Idris, 2014; Veverita, Kusumastusti, \& Rachmawati, 2017). Therefore, they require 
adequate information from the products' supply chain to ascertain the integrity of its halal status. Besides, Muslims are bound with Islamic rules in doing business which is called Mu'amalah principles. Not only the goods must be halal, but the transactions must be free from riba' or usury, uncertainty, and gambling elements.

In an online trading, consumers would refer to the sellers' website to gain information and make informed decisions. But, some e-commerce sites that are available now have too many products and incomplete information that make it difficult for consumers to find the quality ones. Bojang (2017) and Humaizi, Asmara, Sis \& Yusof (2020) indicated that the website interface is considered having major influence on online consumers trust. In the study focused on B2C e-commerce consumers, the researcher recommended in order to enhance users' navigation and satisfaction, online vendors need to develop informative and user-friendly websites.

The emergence of the internet technology in the trading environment has created ecommerce as the powerful communication medium in information systems. Both internal and external users interact in this medium for business dealings. Customers, suppliers and business owners are the users of e-commerce system who will make decisions and execute business transactions. These actions will give impacts to individual, organizations, industry or national economies.

Most e-commerce success researches typically applied various success models that evaluates factors internal to the systems such as information quality, system quality, technology characteristics, and factors external to the system such as service quality, usage, and user satisfaction. DeLone and McLean Information System Success Model (D\&M) has been claimed to be a generic model of information system success (DeLone \& McLean, 2003) that can be used to study e-commerce effectiveness (Li \& Sun, 2009). The D\&M model itself is built on communication theory, thus this communication and trading process may fit nicely into the D\&M success model 2003. Thus, this study used D\&M model because it is one of the best and most-cited model used to evaluate the success of information systems especially in the context of ecommerce (e.g. Li \& Sun, 2009; Mahmoodi et al., 2017; Balogun, Ahlan, Mejabi \& Olayowola Bello, 2017), applying it to the halal industry context, to measure the effectiveness and success of halal e-commerce platforms in Malaysia.

\subsection{Information quality}

As indicated by Delone \& McLean (2003), information quality is an important consideration in adoption process of information systems. In order to implement ecommerce successfully, all the quality aspects of the system, especially information quality should be deliberately considered (Pardo, Brandt \& Puerta, 2018). According to this model, information quality has been used as measures of information systems output that meet the criteria of completeness, ease of understanding, personalization, relevance to decision making and security. D\&M IS Success Model indicates that the understanding of the system quality and information quality is very relevant to manage the e-commerce related activities.

Information is a resource that needs to be managed efficiently. As competition in business environment is becoming more intense in this day, organizations were 
pushed to acquire qualified information in order to be sustainable in the market (Chong et al., 2014). According to Somers, Gorla and Wong (2010), information quality refers to the quality of outputs the information system produces which can be in the form of reports or online screens.

Information quality describes the value of information presented by websites as perceived by users (Qutaishat, 2013). Users want the information provided displays completeness, ease of understanding, personalization, relevance, and security, so that their confidence in doing the transactions can be increased, thus will enhance their satisfaction (DeLone and McLean, 2003; Huang \& Chen, 2017).E-commerce offers the consumer or enterprise various information they need, making information into total transparency (S.Sridhar, 2017\& Zhou, et.al., 2018). This transparency criteria is very crucial in halal e-commerce because both parties required quality information to make decisions. Consumers depends on information provided by the website to know the halal status of the products before making the purchase. High quality information can help consumers in making a quick and efficient decision to purchase of appropriate or difficult-to-find products.

Moreover, the environment of halal businesses operating is a complex environment that require certain regulations and guidelines to be complied (Tahir, 2013). The environment they are operating should be in compliance and strictly follow Islamic principles. This specific requirement will result in distinct practices of information management so that the objective of halal business can be achieved. To manage the information and to make sure they are in certain standard of quality is quite a challenge, especially in digital environment. Many business owners were found reluctant to share information as they perceived the act will reduce companies' competitiveness and sustainability (Chong et al., 2014).

Gao et al., (2012) stressed that among the key to success in e-commerce is to supply buyers with sufficient information to help them find and purchase the products applicable to their needs. Previous studies by Hao, Duo-lin, and Zhi-jie (2010) have revealed that when consumers obtain more complete product information from shopping websites, they tend to be better prepared for the decision-making process and more convinced that the information delivered by the business is relevant and adequate as their requirements.

\section{Methodology}

This study seeks to identify the critical information quality characteristics in halal e-commerce that comply with Islamic business practices.Thus, the combination of exploratory and explanatory qualitative case studies approach was adopted, with the hope it could help us to understand the situation or problem and discuss them by analysing the perspectives and experiences of the participants from the support of qualitative data gathered (Yin, 2011). The approach allowsus to obtainfieldbasedinsights from key information custodians of halal e-commerce platforms and also to explore activities or transaction processes relating to halal e-commerce information management. In addition, Myers and Avison (2002) stated that a case 
study design is suitable for studies where capturingtheknowledgeofpractitionersis needed, and this study bases its contribution on data collected from foure-commerce platform providers that operate in Malaysia.

In order to gather views and experiences needed, semi-structured in-depth interviews were conducted with participants from four halal e-commerce platforms in Malaysia, which form a focal point of four case studies. The four cases were chosen because of these criteria:

- The firms provide an online platform for operating businesses.

- The firms offered only halal products or services.

- The firms must satisfy the halal B2C criteria.

- The firms have at least interactive website, sales and payments online.

By choosing these cases, the researcher will be able to collect rich data about these organisations and conduct in-depth analysis on what they were doing by interviewing the managers or decision makers in the organisations.Moreover, the use of more than one case studies can help to better understand and compare the application of ecommerce in different organizations and help to develop or enhance the theory (Sila, 2015). Table 1 shows the details of the case studies selected.

Table 1. Overview of organizations

\begin{tabular}{|l|c|l|l|}
\hline \multicolumn{1}{|c|}{ Case } & $\begin{array}{c}\text { Year of } \\
\text { establishment }\end{array}$ & \multicolumn{1}{|c|}{ Business Nature } & \multicolumn{1}{c|}{ Description } \\
\hline A & 2015 & $\begin{array}{l}\text { Halal e-commerce } \\
\text { marketplace }\end{array}$ & $\begin{array}{l}\text { The world's first B2C e-marketplace offering } \\
\text { premium quality Halalan Toyyiban products and } \\
\text { services }\end{array}$ \\
\hline B & 2007 & $\begin{array}{l}\text { R\&D of organic health } \\
\text { products }\end{array}$ & $\begin{array}{l}\text { The Malaysia leading healthcare and wellness with } \\
\text { central focus on the well-being of their customers. } \\
\text { The Group also operates a diverse portfolio of } \\
\text { businesses in agri-biotechnology, secure-technology, } \\
\text { healthcare and wellness. }\end{array}$ \\
\hline C & 2018 & Service & $\begin{array}{l}\text { The company operates an integrated apps that } \\
\text { provides guidance and service for umrah package }\end{array}$ \\
\hline D & 2009 & Halal food manufacturer & $\begin{array}{l}\text { A well-known fish crackers producer in east coast } \\
\text { that aggressively does innovation in its food products } \\
\text { and among the first that provides online commerce. }\end{array}$ \\
\hline
\end{tabular}

The cases were chosen through purposive sampling. The sample had been identified based on their characteristics as previously mentioned. Based on Marshall and Rossman's (1995) recommendation, the selection of the participants was based on their level of management, involvement, responsibility and role in e-commerce application. Among the important people interviewed were business owners and top managers of the organisations. These people involve directly or indirectly in decision making and managing e-commerce application. Regarding the selection of the interviewees, Yin (2003) and Eisenhardt and Graebner (2007) advised to choose people with different positions and from different hierarchical levels in the organizations to be interviewed. Snowball sampling was used to identify people who worked with the system. 
Prior to the interview session, we sought permission for the company's participation by sending them a formal letter. Then, after getting approval, the interview questions were send to the respondents so that they can be well-prepared to contribute to answer the questions. The respondents were required to sign the consent form if they agree to participate in the interview. The issues discussed during the interview included the criteria of information quality of e-commerce which is in accordance with Sharia requirements, and how the business uphold the halal concepts and the quality aspects in the online transactions. The face-to-face interviews lasted on average 80 minutes. The in-depth semi-structured interview were digitally recorded and then transcribed.

Regarding data analysis, Yin (2009) suggested a pattern-matching logic as the most common or useful procedures for case study analysis. The method compares an empirically-based pattern (one that revealed by the outcome of the case study) with what is expected to occur (a predicted pattern). If the patterns overlap or match, the initial proposition is confirmed and the results can help to strengthen the case study's internal validity. In addition, content analysis is also widely used in qualitative research that tries to describe and quantify phenomena.

\section{Results}

Providing a qualified information is the responsibility of top management, as one interviewee stated "the coordination between marketing team and IT team determines this information and the final decision is made by the head of marketing department". This statement was agreed by all participants across the different case study organisations who also highlighted the quality of being trustworthy, clarity, timeliness, completeness and the format or presentation of information as very crucial to be observed in halal e-commerce platforms. The reliable and verified information created some trustworthy criteria that help increase the credibility of their platforms.

\subsection{Reliable}

In the era of technology, information is always abundant. But, only reliable information is useful for decision making. When searching for halal product through websites, customers can depend on the information which has a credible source. For example, information must be supported with halal logo, halal certification, and direct links to authoritative bodies.

The president of Case B explained that the reliability criteria can be reinforced when company is committed to practising the goodness in the whole business processes. Meanwhile, the manager from Case $\mathrm{C}$ who developed apps for his company insisted that the use of technology can enhance the quality of information. He said that some umrah (Muslims pilgrimage) agents deliver information to customers through talks or lecture sessions and using flyers and brochures. This kind of practice produced unstandardized set of information which may confuse customers. In particular, the information produced by the authoritative source was more reliable. 
Having third party verification towards the information supplied into e-commerce transactions can confirm the truth of the content thus make the information more reliable.

\subsection{Verification}

Another important requirement in providing information for halal products is verification by authoritative bodies. A company can claim its products are halal if only they have certificate from The Department of Islamic Development Malaysia (JAKIM) and other recognised Halal Certification Bodies (CBs). All participants unanimously agreed that third party's verification is crucial to establish an operation of halal e-commerce platform. As stated by Halal Advisor of Case A; "For me, the most important thing is our involvement with the authority ... on what basis we refer to the authority".

The Vice President of Case A specified that they also required their suppliers to get certificate to ensure the status of the products to be advertised in the platform. The company will assist their suppliers, including the producers from outside Malaysia, to apply for the certification. He further emphasized that the role to certify the halal status remains on the responsibility of CBs.

In another business context, servicing agent for umrah and tours proposed the use of apps to simplify the verification process. The e-commerce platform gathers information input to be supplied to the website from marketing team and department leaders. These groups will discuss with web management team to update any events, news or current changes needed in the website. The communication among these teams help to determine only verified information will be provided to customers. However, the decision and permission from the company's CEO is needed before the information is disseminated to outside parties.

\subsection{Clarity}

Moreover, requirement analysis for information quality needs the clarity of the information. A clear information is usually presented in an understandable manner, concise and complete. Case A participants elaborated in details on how sometimes the information was better explained if supported by pictures. He further added that some conventional e-commerce platforms caused major problem by trying to confuse customer with vague description of product information.

In the same aspect, the Marketing Director of Case B argued that the content and accuracy of information is crucial for decision-making. The President of Case B added that the quality of the e-commerce platform was determined by the quality of what were being advertised by the company in the website. He also said a company should reflect the halal status it has obtained not only in certificate but also in the whole business processes.

While the manager of Case $\mathrm{C}$ believed that unclear and inadequate information may be misleading thus causes frustration to customers. Therefore, a clear 
information must contain all relevant facts and figures and must be presented in an understandable manner to influence decision-making.

\subsection{Format / presentation}

The way an information is presented in the website may affect users' understanding of its content. Sometimes, this is related to the technical aspects of the website such as web design, layout, and complexity of the instructions. These factors make users easily bored and tired thus stop looking for the information. Also, the use of simple words and avoid the use of too much jargons could help users understand better.

The Senior Vice President of Case A explained how they guided halal manufacturers, especially small businesses, to properly put information about their products before it was advertised in the halal platform. This is because many small businesses produced good products but failed to present it in convincing techniques, in terms of proper packaging, branding, etc. According to him, this practice is important to demonstrate all the quality aspects has been accomplished in halal business.

Another manager explained how the presentation of information should be; "It is (more understandable) with a proper layout and alignment of the content, and also design of the information" (General Manager, Case B). He repeatedly stressed on the format of the information and suggested the way of information delivery should be based on preference of customers. He said "normally videos are preferred to photos or write-ups..." His opinion was supported by the Brand Manager of Case $\mathrm{C}$ who stated that the use of videos in delivering online materials leads to more standardized information.

\subsection{Timeliness}

Another criterion for a good quality information is timeliness aspect. It refers to the accessibility and availability of information at the time suitable for its use. As pointed out by one interviewee, an information should be current to be relevant for decision making. An information should always be updated so that it reflects a current situation of the company. The General Manager of Case B added to his point that "The information should have regular updates." His statement is also supported by informant from Case C and Case B who emphasized the significance of updated information in their business.

The timely information is very crucial for halal business because halal logo and certificate have certain expired date. The business is normally given a two-year period with certification and needed to renew it after satisfying all the requirements. But, if irresponsible business owner kept using the expired logo or certification, the information will be misleading to consumers. 


\subsection{Completeness}

In order for information to be useful it needs to be complete. If parts of the information are missing, then users will not be able to make use of it or make accurate decisions. In Case A, they always redirect customers to halal authorities' website if they want to get more detailed information.The Brand Manager of Case $\mathrm{C}$ was confident with the use of umrahapps, they can provide customers with extra information than normally practised in traditional way of disseminating information. He further insisted that the apps is very useful, acted as a companion that offers guidelines to pilgrimages from time to time.

When the information is incomplete, it will both distress the company and customers. Case D officer acknowledged that customers sometimes forgot to fill in complete posting address such as street name or postcode, thus the marketing team have to contact them by phone number before they proceed with product delivery. If the customer cannot be reached (by contact number), but the payment had been received, the company will wait until the customer call back asking their order then the company will deliver it. This is to avoid risk of product damage because the product cannot be delivered. At times, there are also cases where customers laidback on using the website makes them unable to find complete information. They ended up calling customer service who will direct them on how to complete the transactions.

\section{Discussion}

Information is a valuable resource for all organizations. As competition in business environment is becoming more intense, organizations were pushed to acquire qualified data and information in order to be sustainable in the market (Chong et al., 2014). Information quality describes the value of information presented by websites as perceived by users. Many previous studies found that users want the information provided displays completeness, ease of understanding, personalization, relevance, and security, so that their confidence in doing the transactions can be increased, thus will enhance their satisfaction (DeLone and McLean, 2003; Qutaishat, 2013; Huang \& Chen, 2017).

Consumers highly depends on information provided by the website to know the halal status of the products before making the purchase. Therefore, the sellers must provide transparent information such as to disclose all the ingredients, contents, origin/manufacturer, and verified halal status of the products. From this study, the main criteria of qualified information as perceived by key information custodians in halal e-commerce platforms are reliability, verification, clarity, presentation, timeliness and completeness.

Interestingly, the consensus between the participating companies with regard to the information quality required to be provided in halal e-commerce platforms is significantly strong. These e-commerce providers agreed that the information about halal status of the products must be reliable. Customers can always find information from any sources. But, reliable information would come from a reliable source. That's mean, to make the information trustworthy, it must be verified by relevant parties. 
Customers always need to use their critical judgment to decide which information can be trusted. It is because a source in a printed or posted in Web does not automatically make it trustworthy.

Therefore, halal certification is one of the means to verify the information. A study by Khan and Haleem (2016) supposed that among the benefits of halal certification was helping customers make an informed and quick decision at the time of purchase. Customer does not have to bother checking all the ingredients and searching for another source if the product already had the halal certificate. Moreover, information presented in a proper format and timely manner would increase the understandability of users. The clarity of information influenced customers' decision to choose halal products. This goes with the results of the studies carried out by (Bashir, 2019 and Zailani et al., 2015).

Likewise, the D\&M IS Success Model already indicated that the information quality has been used as measures of information systems output that meet the criteria of accuracy, reliability, information timeliness, relevance to decision-making, completeness, understandability, etc. Thus, as one of the most widely used channel for shopping, e-commerce platforms must have those criteria observed. What is more, the global halal industry has become a developing market for both Muslim and nonMuslim consumers. More businesses are venturing into the halal industry to tap the market (Ali, 2018). Therefore, providing a qualified information is very crucial to satisfy both group of consumers.

Living inherently in Islam, every Muslims are required to seek for truthful and reliable information. In the swift development of Internet and social media, information become abundant and there are imperatives requiring the needs to identify the right and most accurate information. Al-Haytham who is considered by many to be the first Muslim scientist wrote, "The duty of the man who investigates the writings of scientists, if learning the truth is his goal, is to make himself an enemy of all that he reads, and... attack it from every side,". He further wrote. "He should also suspect himself as he performs his critical examination of it, so that he may avoid falling into either prejudice or leniency". Basically, Ibn al-Haytham's message is, when we get any information, one must not take the writings and explanations at face value but must indeed verify it. That means, critical thinking and a demand for proof was a prevalent aspect of Muslim practice.

\section{Conclusion}

Organizations managed their information in order to meet the needs of management and customers that depend on that information. It also allowed the information to be presented to the audience or the correct group of people. Only after individuals are able to put that information to use, it then gains more value. Besides, the infrastructure used in carrying out the transactions should also be managed efficiently. These infrastructure including hardware and software require some investment from organization's resources. Therefore, if managed efficiently it would generate benefits to the investors. Another aspect to be emphasized is service quality 
and support to customers so that their shopping experience in halal e-commerce would be enhanced.

Taken together the criteria presented from the four case studies show that a blending of well-established measures and newcriteria is needed. These measures (i.e information quality, systems quality, and service quality), however, are not new to the overall structure or framework provided by the DeLone \& McLean Information Systems Success Model.Also, most of the criteria(i.e. reliability, verification, clarity, presentation, timeliness and completeness) found in this study are criteriaalready used in information system research. But, the major differences are context and focus. In the halal e-commerce environment, the information system users are mostly Muslim consumers and halal businesses, and the purpose of the system is primarily the execution of business transactions according to Islamic mua'malah. Thus, the halal ecommerce context requires a new set of criteria to be explained. Still, the updated DeLone and McLean model fitted into the study and can serve as an appropriate ramework for organizing halal e-commerce success criteria.

\section{$7 \quad$ Limitations}

There is a methodological limitation of the study should be mentioned here. There is the unbalanced availability of data in each of the discussed case studies, where there was only one interview in one of the cases. However, in that case an interviewee was a person in a position that could shed light on arrange of activities related to the researched phenomenon. The author also made observations on the firms' website, to see how they presented information to users. Therefore, this observation allowed us to address respondent bias and enabled triangulation of data to increase the trustworthiness of the findings (Yin, 2014; Singh, Zolkepli and Cheah, 2018)

\section{Acknowledgement}

This paper is based on work supported by the Fundamental Research Grant Scheme (FRGS) SO Code: 13812. The author expresses her appreciation to the Ministry of Higher Education Malaysia for the grant and UUM for their endless support.

\section{References}

[1] Bojang, I. (2017). Determinants of Trust in B2C E-Commerce and Their Relationship With Consumer Online Trust: a Case of Ekaterinburg, Russian Federation. Journal of Internet Banking and Commerce, 22(S8), 59. https://doi.org/10.1063/1.5013938

[2] Delone, W. H., \& McLean, E. R. (2003). The DeLone and McLean Model of Information Systems Success : A Ten-Year Update. Journal of Management Information Systems, 19(4), 9-30. https://doi.org/10.1080/07421222.2003.11045748

[3] DeLone, W. H., \& McLean, E. R. (2016). Information Systems Success Measurement. In A. R. Dennis (Ed.), Foundations and Trends in Information Systems (pp. 1-116). 
[4] Huang, M., \& Chen, T. (2017). Tourism Website Customers 'Repurchase Intention: Information System Success Model. In 7 International Conference on Applied Mechanics and Mechanical Automation (AMMA 2017) (pp. 426-430). https://doi.org/10.12783/dtetr/ amma2017/13399

[5] Humaizi, H., Asmara, S., Sis, R., \& Yusuf, M. (2020). The Use of Online Marketplace Website in Indonesia: A Study of Consumers' Motives and Gratification. https://doi.org/10.3991/ijim.v14i07.11385

[6] Iskandar, M., Tan, I., Razali, R. N., \& Husny, Z. J. (2012). The Adoption of Halal Transportations Technologies for Halal Logistics Service Providers in Malaysia, 6(3), 737744.

[7] Ismaeel, M., \& Blaim, K. (2012). Toward applied Islamic business ethics: responsible halal business. Journal of Management Development, 31(10), 1090-1100. https://doi.org/10. $1108 / 02621711211281889$

[8] Jusop, M., Ismail, R. M., \& Ismail, N. A. (2018). Understanding Halal E-Commerce Practice: A Proposed Conceptual Framework. Global Business \& Management Research, $10(3)$.

[9] Muhammad, M., Muhammad, M. R., \& Khalil, K. M. (2013). Towards Shari ' ah Compliant E-Commerce Transactions : A Review of Amazon . com. Middle-East Journal of Scientific Research, 15(9), 1229-1236. http://doi.org/10.5829/idosi.mejsr.2013.15.9.11176

[10] Muhammad, M. R., \& Muhammad, M. (2013). Building Trust in E-Commerce: A Proposed Shari' ah Compliant Model. Journal of Internet Banking and Commerce, 18(3), 1-13.

[11] Muhammad, M. Z., Amboala, T., Ghazali, M. F., \& Hassan, Z. (2011). Comprehensive Approach for Sharia ' Compliance E-Commerce Transaction. Journal of Internet Banking and Commerce, 16(1), 1-14.

[12] Ngah, A. H., Zainuddin, Y., \& Thurasamy, R. (2017). Applying the TOE framework in the Halal warehouse adoption study. Journal of Islamic Accounting and Business Research, 8(2), 161-181. https://doi.org/10.1108/jiabr-04-2014-0014

[13] Othman, B., Shaarani, S. M., \& Bahron, A. (2016). Evaluation of knowledge, halal quality assurance practices and commitment among food industries in Malaysia. British Food Journal, 118(8), 2033-2052. https://doi.org/10.1108/bfj-12-2015-0496

[14] Parasuraman, A., Zeithaml, V. A., \& Malhotra, A. (2005). E-S-QUAL A Multiple-Item Scale for Assessing Electronic Service Quality. Journal of Service Research, 7(3). https://doi.org/10.1177/1094670504271156

[15] Pardo Kuklinski, H., Brandt, J., \& Puerta, J. P. (2008). Mobile Web 2.0. A theoreticaltechnical framework and developing trends. International Journal of Interactive Mobile Technologies (iJIM), 2(4), 54-61.

[16] Pee, L., Jiang, J., \& Klein, G. (2018). E-store loyalty: Longitudinal comparison of website usefulness and satisfaction. International Journal of Market Research, 1-17. https://doi.org/10.1177/1470785317752045

[17] Qutaishat, F. T. (2013). Users' Perceptions towards Website Quality and Its Effect on Intention to Use E-government Services in Jordan. International Business Research, 6(1), 97-105. https://doi.org/10.5539/ibr.v6n1p97

[18] Rahayu, R., \& Day, J. (2017). E-commerce adoption by SMEs in developing countries: evidence from Indonesia. Eurasian Business Review, 7(1), 25-41. https://doi.org/10.1007/ s40821-016-0044-6

[19] Rahman, R. A., Rezai, G., Mohamed, Z., Shamsudin, M. N., \& Sharifuddin, J. (2013). Malaysia as Global Halal Hub: OIC Food Manufacturers Perspective. Journal of International Food \& Agribusiness Marketing, 25(1), 154-166. https://doi.org/10.1080/ $\underline{08974438.2013 .809672}$

[20] Ramdani, B., Kawalek, P., \& Lorenzo, O. (2009). Predicting SMEs' adoption of enterprise systems. Journal of Enterprise Information Management, 22(1/2), 10-24. https://doi.org/10.1108/17410390910922796 
[21] Ribadu, M. B., \& Rahman, W. N. W. A. (2016). A generic framework for e-commerce requirements to comply with Sharia in business-to-consumer perspective. Proceedings of 2016 SAI Computing Conference, SAI 2016, 752-757. https://doi.org/10.1109/sai.2016. $\underline{7556064}$

[22] Ribadu, M. B., \& Wan Ab. Rahman, W. N. (2017a). An integrated approach towards Sharia compliance E-commerce trust. Applied Computing and Informatics, 1-6. https://doi.org/10.1016/j.aci.2017.09.002

[23] Ribadu, M. B., \& Wan Ab. Rahman, W. N. (2017b). Sharia Compliance Service Quality Metrics for E- Commerce: an Exploratory Analysis. In J. \& N. H. Z. Zulikha (Ed.), Proceedings of the 6th International Conference on Computing and Informatics, ICOCI 2017 (pp. 332-340). Retrieved from http://icoci.cms.net.my/PROCEEDINGS/2017/ Pdf_Version_Chap06e/PID147-332-340e.pdf

[24] S.Sridhar. (2017). E-Commerce Technology Made Easy. International Journal of Innovative Technology and Research, 5(3), 6183-6198.

[25] Shin, D.-H. (2017). Conceptualizing and measuring quality of experience of the internet of things: Exploring how quality is perceived by users. Information \& Management. https://doi.org/10.1016/j.im.2017.02.006

[26] Shkoukani, M., Badran, O., \& Lail, R. A. B. U. (2017). A Proposed Model of E-Commerce using Modern Social Media and Its Impact on Consumer Loyalty. Journal of Theoretical and Applied Information Technology, 95(8), 1626-1636.

[27] Shrivastava, S., \& Pateriya, R. K. (2018). Secure Framework for E-Commerce Applications in Cloud Environment. Improving E-Commerce Web Applications Through Business Intelligence Techniques, 82-109. https://doi.org/10.4018/978-1-5225-3646-8.ch004

[28] Sila, I. (2015). The state of empirical research on the adoption and diffusion of business-tobusiness e-commerce. International Journal Electronic Business, 12(3), 258-301. https://doi.org/10.1504/ijeb.2015.071386

[29] Simpson, M., \& Docherty, A. J. (2004). E-commerce adoption support and advice for UK SMEs. Journal of Small Business and Enterprise Development, 11(3), 315-328. https://doi.org/10.1108/14626000410551573

[30] Singh, S. (2017). The Effect of Shopping Platform and Product Type on Antecedents of Online Consumer Behaviour - A Proposed Framework. Journal of Internet Banking and Commerce, 22(June), 1-16.

[31] Singh, S., Zolkepli, I. A., \& Kit, C. W. (2018). New wave in mobile commerce adoption via mobile applications in Malaysian market: investigating the relationship between consumer acceptance, trust, and self efficacy. International Journal of Interactive Mobile Technologies (iJIM), 12(7), 112-128. https://doi.org/10.3991/ijim.v12i7.8964

[32] Siregar, R. A. S., Qadrya, H. A., Caroline, B. M., Sari, A. P., Renanda, T., Lazuardi, L. I., \& Arbi, R. (2017). Analisis transaksi jual-beli online (peer to peer) pada e-commerce berdasarkan hukum syariah. Journal of Islamic Economics Lariba, 3(1), 31-38. http://doi.org/10.20885/jielariba.vol3.iss1.art4

[33] State of the Global Islamic Economy Report. (2015). Thomson Reuters.

[34] Tahir, P. R. (2013). Moderating Role of Marketing Environment on the Lead Success Factors of Halal Small and Medium Eenterprises in Pahang. University of Malaya, Kuala Lumpur.

[35] Turban, E., Outland, J., King, D., Lee, J. K., Liang, T.-P., \& Turban, D. C. (2018). Electronic Commerce 2018: A Managerial and Social Networks Perspective (Ninth ed.). Springer International Publishing. https://doi.org/10.1007/978-3-319-58715-8

[36] Vellaisamy, K., Baharudin, A. S., Karkonasasi, K., \& Mousavi, S. A. (2017). Factor Affecting User Adoption towards Internship and Career Portal in Malaysia. Indian Journal of Science and Technology, 10(33), 1-6. https://doi.org/10.17485/ijst/2017/v10i33/80079 
[37] Veverita, Kusumastusti, R. D., \& Rachmawati, R. (2017). Motives and Challenges of Small Businesses for Halal Certification: The Case of Indonesia. World Journal of Social Sciences, 7(1), 136-146.

[38] Wahab, N. A., Shahwahid, F. M., Ab.Hamid, N. A., Othman, N., Ager, N. S., Abdullah, M., ... Saidpudin, W. (2016). Contributions of Malaysia and Singapore in the Development of Halal Industry in the ASEAN Region. Asian Journal of Social Sciences \& Humanities, 5(2), 37-46.

[39] Wang, Y. S. (2008). Assessing e-commerce systems success: A respecification and validation of the DeLone and McLean model of IS success. Information Systems Journal, 18(5), 529-557. https://doi.org/10.1111/j.1365-2575.2007.00268.x

[40] Watabaji, M., Molnar, A., Weaver, R. D., Dora, M., \& Gellynck, X. (2016). Information sharing and its integrative role: an empirical study of the malt barley value chain in Ethiopia. British Food Journal, 118(12). https://doi.org/10.1108/bfj-11-2015-0423

[41] Wei, C., Yu, Z.-J., \& Chen, X.-N. (2017). Research on social e-commerce reputation formation and state-introduced model. Kybernetes, 46(6). http://doi.org/10.1108/K-08-20160203. https://doi.org/10.1108/k-08-2016-0203

[42] Wei, T. T., Marthandan, G., Chong, A. Y., Ooi, K., \& Arumugam, S. (2009). What drives Malaysian m-commerce adoption? An empirical analysis. Industrial Management \& Data Systems, 109(3), 370-388. https://doi.org/10.1108/02635570910939399

[43] Xin, G. (2017). A Study of Multimodal Banner Discourse on Chinese E-Commerce Websites From the Perspective of Discourse Information. Cross-Cultural Communication, 13(6), 1-10. http://doi.org/10.3968/9801

[44] Yin, R. K. (2011). Qualitative Research from Start to Finish. The Guilford Press.

[45] Yu, P., \& Qian, S. (2018). Developing a theoretical model and questionnaire survey instrument to measure the success of electronic health records in residential aged care. PLOS ONE, 13(1), 1-18. https://doi.org/10.1371/journal.pone.0190749

[46] Zainul, N., Osman, F., \& Mazlan, S. H. (2004). E-Commerce from an Islamic perspective. Electronic Commerce Research and Applications, 3, 280-293. https://doi.org/10.1016/ j.elerap.2004.01.002

[47] Zeithaml, V. A., Parasuraman, A., \& Malhotra, A. (2002). Service Quality Delivery through Web Sites: A Critical Review of Extant Knowledge. Journal of the Academy of Marketing Science, 20(4). https://doi.org/10.1177/009207002236911

[48] Zha, X., Yang, H., Yan, Y., Liu, K., \& Huang, C. (2017). Exploring the effect of social media information quality, source credibility and reputation on informational fit-to-task: Moderating role of focused immersion. Computers in Human Behavior. https://doi.org/10. 1016/j.chb.2017.10.038

[49] Zhang, M., Chen, M., \& Zuo, W. (2017). How to Avoid Credit Risk of Network Shopping with the Establishment of Reputation Mechanism of E-Commerce Enterprises. In The Sixteenth Wuhan International Conference on E-Business (WHICEB 2017).

[50] Zhijun, K. (2009). A Framework for Investigating the Impact of IT and E-Commerce Capability on Firm Performance : A Resource-Based View. IEEE, 0-3.

[51] Zhou, T., Lu, Y., \& Wang, B. (2010). Integrating TTF and UTAUT to explain mobile banking user adoption. Computers in Human Behavior, 26(4), 760-767. https://doi.org/10. 1016/j.chb.2010.01.013

[52] Zhu, K., \& Kraemer, K. L. (2014). Post-Adoption Variations in Usage and Value of EBusiness by Organizations : Cross-Country Evidence from the Retail Industry. Information Systems Research, 16(1), 61-84. https://doi.org/10.1287/isre.1050.0045

[53] Zhu, K., Kraemer, K. L., \& Xu, S. (2006). The Process of Innovation Assimilation by Firms in Different Countries: A Technology Diffusion Perspective on E-Business. Management Science, (September 2014). https://doi.org/10.1287/mnsc.1050.0487

[54] Zhu, L., Thatcher, S. M. B., \& Thatcher, M. E. (2014). Institutional Environment for Business-to-Business (B2B) E-Commerce Usage: Toward an Understanding in the Chinese 
Context. Journal of Information Technology Case and Application Research, 16(January 2015), 127-154. https://doi.org/10.1080/15228053.2014.987612

\section{Authors}

Mariana Jusop is an accounting lecturer in the Faculty of Business and Management at the University Sultan Zainal Abidin (UniSZA), Malaysia. She has been a faculty member since 2010 and now pursuing her $\mathrm{Ph} . \mathrm{D}$ at University Utara Malaysia. Her research interests lie in the area of accounting and business information systems, ranging from theory to current issues in business. These include issue of halal, information management, and information technology adoption. She has also collaborated actively with researchers in several other disciplines such as computer science, particularly in determining information needs for small businesses' software adoption. Email: mariana.jusop1982@gmail.com

Dr. Risyawati Mohamed Ismail is an operation lecture in the School Technology Management and Logistics, Universiti Utara Malaysia (UUM) since 2010 and the current Director of Food security, Innovation \& Development Research Centre, UUM. She is a Curriculum Assessor for Malaysia Qualification Agency (MQA) on Halal and Halal Industry Management since 2014, a JAKIM certified halal trainer and a member of Halal Professional Board Malaysia. Her research interest includes halal ecosystem and food safety. Her involvement in the halal food industry started in 1998, when she was attached to several MNCs in the food and health care industries. During her time in the industry, her work functions ranged from QA Executive to QA Manager and finally to QA Consultant to several, local SMEs. Through her 15 years in the industry, she has had first-hand experiences in relation to various food quality standards that include MeSTI, GMP, HACCP, Food Safety Management System (ISO 22000:2005) certifications and Halal Assurance System (HAS), taking the role of coordinator, implementer, and auditor and gradually as Quality Management Representative (QMR). She has been exposed to hands on halal industry issues and over time has taken the role of the leader of the halal committees in her various positions in the food industry. Email: risyawati@uum.edu.my.

Professor Noor Azizi Ismail is the current Vice Cancellor of UMK. He has authored more than 100 academic articles during his tenure as an academician. His research interest is mainly on accounting system and technology driven economy. noorazizi@umk.edu.my

Article submitted 2020-06-26. Resubmitted 2020-07-26. Final acceptance 2020-07-29. Final version published as submitted by the authors. 